\title{
Erratum zu: Ausgewählte Texte zur Entstehung der Psychologie als Wissenschaft
}

\section{Erratum zu: \\ G. Eckardt, Ausgewählte Texte zur Entstehung der Psychologie als Wissenschaft, https://doi.org/10.1007/978-3-658-25790-3}

Die Originalversion dieses Buches wurde versehentlich mit einer falschen Literatur veröffentlicht. Die Literatur „Wundt, W. (1892c). Zur Frage des Bewußtseinsumfanges. Bd. 2. Leipzig: Engelmann.“ wurde in „Wundt, W. (1892c). Die Methoden der Messung des Bewußtseinsumfanges. (In: Wundt, W. [1911]. Bd. 2. 171-182). Stuttgart: Kröner.“ aktualisiert.

Die aktualisierte Version des Buches finden Sie unter https://doi.org/10.1007/978-3-658-25790-3 